XVI.-Description of an apparently new Species of Pheasant belonging to the genus Argus. By D. G. Elliot, F.L.S., F.Z.S., \&c.

The form of Argus-Pheasant to which I desire to call the attention of ornithologists is founded merely upon a few feathers of the wing and tail ; but meagre as my materials may be, they are sufficient to establish the species, should the rest of the plumage of the bird hereafter be ascertained to accord with the feathers we now have, in presenting and continuing those characteristics which cause these to differ from the other known species of Argus. To suppose that such would be the case is not by any means a great stretch of the imagination; and it is no more difficult to establish a species upon a single feather than it is to reconstruct a skeleton from a single bone, which has frequently been accomplished with the happiest results. The species $I$ now describe is represented in the Paris Museum by four feathers, one long central one of the tail and three of the wing, differing altogether in colour and markings from all others with which I am acquainted. They have been known for some considerable time to naturalists as Argus ocellatus; but although the name has been frequently used in different ornithological works, no description of these feathers has ever been published-an omission I now propose to supply.

\title{
Argus ocellatus.
}

Argus ocellatus, J. Verr. MS.; Bon. Compt. Rend. t. xlii. p. 878 (desc. null.); Sclat. Proc. Zool. Soc. (1863), p. 124; Gray, List Gall. (1867), p. 26.

\section{Hab. — ?}

The largest primary is dark brown upon the outer portion of the outer web, and for about two-thirds of its length from the tip is barred with blackish brown, and also mottled with the same, chiefly in the centre of the web. The base of the feather and also both sides of the shaft are light rufous buff, unspotted, the outer margin of the inner web being brown faintly dotted with dark brown. The buff colour of the base extends the whole length of the feather, becoming darker at the tip. The smallest feather differs from the one just described by only having the base and a line along the shaft of the inner web for half its length bright buff, the remainder being dark brown barred and mottled with blackish brown on the outer web, and only faintly dotted with dark brown on a small portion of the inner web from about halfway from the 
base towards the tip. The shaft is yellowish white for about half its length from the base, with a line of dark brown along the side next to the inner web, becoming generally darker brown as it approaches the tip.

The general colour of the tail-feather is dark ashy grey, becoming reddish on the outer and brownish on the inner web, dotted throughout with small white spots. Along both webs, near the shafts, extending from the base for two-thirds the length of the feather, are numerous rather large reddish spots with black centres, generally of an oblong form, but lengthened out into lines towards the margins; near the tip these reddish markings disappear entirely. The shaft is reddish, blackish brown on the side of the outer web. The feather is very broad, graduating to a sharp point at the tip; its total length is about $4 \frac{1}{2}$ feet.

These feathers do not resemble in any particular that of the A. bipunctatus described lately by Mr. Wood. I shall give full-size representations of all the feathers in my Monograph of the Phasianidæ, now publishing.

\section{XVII.-On the Constitution of Mille and Blood. By M. Dumas*.}

DURING the most troubled years of the first French revolution, the old Academy of Sciences of Paris having been suppressed, its members none the less continued their patriotic cooperation in the labours required by the new necessities of the country. History has given them credit for this. It associates the names of the principal of them with those of the illustrious administrators and generals, who then caused the integrity of the French soil to be respected.

The editors of the 'Annales de Chimie,' who had been compelled to suspend their publication under the reign of Terror, on resuming it had the happy thought of collecting, in two volumes, all the memoirs or reports with which the Academicians had been charged. In running through these we appreciate at a glance the importance of the questions which were addressed to them, the insufficiency of the means at their

* Translated by W. S. Dallas, F.L.S., from the 'Bibliothèque Universelle,' 15 June 1871, Archives des Sciences, pp. 105-119. This paper has been extracted from the 'Philosophical Magazine' for August, as, although its subject does not strictly belong to natural history, some of the author's observations will be of interest to naturalists at the present time. 


\section{$2 \mathrm{BHL}$ Biodiversity Heritage Library}

Elliot, Daniel Giraud. 1871. "XVI.-Description of an apparently new species of Pheasant belonging to the genus Argus." The Annals and magazine of natural history; zoology, botany, and geology 8, 119-120.

https://doi.org/10.1080/00222937108696446.

View This Item Online: https://www.biodiversitylibrary.org/item/86916

DOI: https://doi.org/10.1080/00222937108696446

Permalink: https://www.biodiversitylibrary.org/partpdf/64513

\section{Holding Institution}

Smithsonian Libraries

\section{Sponsored by}

Smithsonian

\section{Copyright \& Reuse}

Copyright Status: Public domain. The BHL considers that this work is no longer under copyright protection.

This document was created from content at the Biodiversity Heritage Library, the world's largest open access digital library for biodiversity literature and archives. Visit BHL at https://www.biodiversitylibrary.org. 